\title{
"Naming the Elephant": Literacy Classism, Human Rights and the Need for a New Conversation.
}

\author{
B. Allan Quigley, St. Francis Xavier University
}

\begin{abstract}
Keywords: adult literacy, marginalized populations, classism

\section{"Adult education is a phrase originally meaning the education of adults who have not been properly educated as children."}

Adult literacy has been on the margins of postsecondary education for so long that many in our field assume our ongoing struggle for adequate funding and a better image is somehow "normal." It is not normal that some 107,000,000 adults across North America are marginalized, with many hidden in society due to low literacy. This article argues it is time to reconsider the position of our field concerning funding and image beginning with a new conversation concerning literacy classism—the "elephant in the room."

Note: My thanks to Margaret Patterson and Leona English for their input to this article.

-Encyclopedia Brittanica, 1953

In an earlier life, I was responsible for the $\mathrm{ABE}$ and GED programs offered through a Canadian province's colleges and career/technical institutions. One of my darkest moments was in a budget meeting seated around the table with other program managers. I had the (rare) opportunity to make the case for more funding for adult literacy and basic education (ALE). I began with the latest "shocking" low-literacy statistics and went on to describe the economic benefits our province could realize with added funding for these programs. I then started in with some of our learners' success stories when, suddenly, a department head interrupted me and, in a too-loud voice, demanded: "Why should we invest more money into programs for "losers?" The ALE budgets were all reduced that year. The reason given was: "lack of resources."

However, virtually all the other college and career/technical programs got an annual increase. The following year saw even more funding cuts to ALE. A grassroots letterwriting campaign arose and the Minister of Advanced Education received hundreds of letters from adult learners and practitioners across the province demanding more funding and improved program access. That year, more funding was found. But only for that year. 
Over the years since, I have asked: "What made the other career/technical programs such higher priorities?" Further, "Why did no one disagree with that blatant 'losers' statement?" Even more important today: "Why has so little changed? After a more than 150-year history of adult literacy education in North America (Quigley, 2017), "Why is adult literacy education still seen as a 'temporary need?" Given our long history and given the sheer numbers of adults living with low literacy: "Why is ALE typically only funded with annual grants?" Further, "Why is long term planning and staff job security so unheard of in ALE?"

This leads to some deeper societal questions. For example, Beder (1991) observed, "[While it is] no longer socially acceptable to publicly denigrate Blacks, Hispanics, and welfare recipients, it is acceptable to denigrate...illiterates." (p. 140). Today, we could add it is unacceptable to denigrate the LGBTQ community, those living with HIV/ AIDS, those with disabilities, the aged, Native Americans; and, here in Canada, First Nations, Métis, and the Inuit. These changes tell us there is hope. Over the past few decades, such previously marginalized populations have gained a voice, at least some levels of respect, and have now some degree of greater equity. Yet, why is it that, "It is still "acceptable to denigrate...illiterates."

We have an estimated 107,000,000 adults living with low literacy in North America, many of whom are hidden in society (Quigley, 2017). This population comprises one of the last major marginalized groups in our society. A population that remains invisible and voiceless.

After almost 50 years as an ALE practitioner, administrator, government worker and academic, I ask a larger question: "Why is our learner population still assumed to be a 'societal problem' needing to be 'solved'?" What other adult education program is seen as a "problem to be solved?" My research leads me to the conclusion the answers lie not in budget meetings, but in the class structure we have inherited from history. Our "elephant in the room" is the hegemony of literacy classism.

\section{The Ladder of Resources and Prestige}

We have a "ladder of resource allocations and prestige" in governmental and postsecondary institutions that consciously or unconsciously mirrors our class structure. Accordingly, adult ALE programs are typically placed on the "lowest rung" of funding and prestige. Meanwhile, in the world of North America's thousands of literacy volunteer tutors and administrators, the ongoing search for funding ranges from government to charities, to bake sales. How can this be understood?

As colleagues and I have discussed elsewhere:

\footnotetext{
An invisible caste system exists in North American society, one that is burdened by wage inequalities, educational discrepancies, government policies and is forgotten in most university and college adult education degree programs...Another term for this 'caste system;' is social class, whereby lower 'castes' are typically the under-educated, under-employed or unemployed lowwage earners (Zacharakis et. al., 2021, p. 420).
}

There is a growing viewpoint that resource allocations for ALE are merely the tip of a societal stigma, a viewpoint I believe should be seen as "literacy classism. If we are to see any real change in our field, we need a new discussion - a discussion that advocates for human rights for adults living with low literacy in our programs and in our society.

\section{Naming the Elephant}

As discussed by Zacharakis et al., the concept of classism denotes: "a negative relation between 
classes where one class treats another class differently based on the first group's perception of cultural values and social status in the second group" (p. 420). As we discussed, having such a view is not always a conscious act; nevertheless, literacy classism is undeniably part of our society. And has been for millennia (Quigley, 2017).

If we turn the clock way back, according to Fischer (2003): "It is possible that the ability to read and write...was one of the distinguishing qualities of aristocracy [as early as] the third millennium BC [sic]" (p. 20). As history tells us, with the rise of the Roman Empire, the skills of "accessing and sharing written knowledge" (Fischer, 2003, p. 149) became so important, so powerful, that the ability to read and write lead to the rise of a privileged class that managed the empire. A privileged class called the litteratus arose (Fischer, 2003, p. 149). As such, "accessing and sharing written knowledge" was exclusively in the language of Latin. Latin, alone, was the accepted "vehicle of Christendom and all learning" (Fischer, 2003, p. 149). As Fischer points out, such societal control by a privileged class, "demonstrates how literacy in any society is not simply a question of who can read and write, but rather the accommodation of prevailing values" (Fischer, 2003, p. 149). From the Roman era we have inherited terms such as "literate," "illiterate," "literacy" and "literature." We have also inherited an age-old prejudice towards those with lower levels of formal education.

\section{Two Reasons for Adult Literacy Education Through Time}

A history of reading and literacy is beyond the scope of this article, but it is significant that the first published history of an organized literacy school for adults in the English-speaking world that had a lasting influence was by Dr. Thomas Pole. Today known as Pole's History (original
1816, reprinted by Verner, 1967), Pole argued the case for teaching adults to read using the Bible. He described the successes of the Bristol School Movement as established in Bristol, England in 1812 and how its religious founders held the fervent belief that reading the Bible would improve the moral conduct of the "illiterate poor." As Pole argued, being able to read the Scriptures would surely inculcate: "the great truths of Christianity amongst those classes of our fellow creatures who have hitherto been unhappily neglected and suffered to remain in a state of lamentable degradation and moral turpitude" (p. 11). Not only that, reading the Bible would mean: "Industry, frugality, and economy will be their possession." And, "they will have also learned better to practise meekness, Christian fortitude, and resignation" (p. 19).

But there was a reason besides morality for teaching the "illiterate Poor" to read. Literacy would reap economic benefits (p. 19). As Pole argued: "Our poor rates will thus be lightened, our hospitals, alms-houses, dispensaries, and other public charities less encumbered" (p. 19).

Here then was the basic two-fold archetype of reasons for supporting adult literacy that we still see today. The rhetoric has changed but the purposes are still: unburdening taxpayers and enhancing the economy, and improving morals and instilling the "prevailing values" of society (Fischer, 2003). These two purposes are not mutually exclusive (Quigley, 2017). The countless negative stereotypes of adults living with low literacy, then and now, are still assumed to be linked. As Stevens (1987) stated: "Bible literacy [in the $19^{\text {th }}$ century] could allow the poor to do their religious duty...it would also help them to acquire the habits of industry and thrift. And a sense of their place in the social order" (p. 107). 


\section{The Peril of the Republic}

Prejudice towards adults with low literacy was widespread in North America in the early years of the $20^{\text {th }}$ century. As President Calvin Coolidge insisted in 1926: "When it is remembered that ignorance is the most fruitful source of poverty, vice, and crime, it is easy to realize the necessity of removing what is a menace [i.e., illiteracy], not only to our social well-being, but to the very existence of the Republic" (as cited in Quigley, 1997, p. 92). During the halcyon days of the War on Poverty, the 1966 Adult Education Act brought adult literacy to the forefront of public attention. The same occurred in Canada with the passing of the federal Adult Occupational Training Act and ALE programs became an established part of postsecondary education on both sides of the US-Canada border.

Literacy campaigns flourished (Quigley, 1997). The media took up the cause and a near "genre" of adult literacy stereotypes grew up in the popular literature. This "genre" was so prevalent that, elsewhere (1997), I was able to discuss whole categories of literacy stereotypes. For example, in the category of "The "Heroic Victim" (1997, pp. 51-53), the public could read how tragic low literate figures were forever "struggling to survive" (p. 51). The Saturday Evening Post claimed: "They suffer in silence and try to hide their problem in shame" (Harr, 1988, p.46). In the Harper's Bazaar, the author tells readers he had, "Never encountered people as hopeless, as sad and as full of loss as those who cannot read or write (Smith as cited in Quigley, 1989, p. 52).

Tellingly, these "heroic figures" were typically White males. The category of "The Simple African American and Simple Southern Whites" (pp. 58-60) was even more demeaning. These onedimensional figures had to "first acknowledge their ignorance and then come humbly, and directly, to the more knowing teacher" (Quigley, p. 58). Only then could they be "saved" by literacy programs. This surge of media stereotypes reached the point that, in 1987, Woodring wrote in the New York Times: "More nonsense is being written about illiteracy than any other subject" (cited in Hechinger, 1987, p. III-7). Nevertheless, what Woodring called "nonsense" in 1987 had had more than a decade to build and reify literacy classism. These demeaning images have been well engrained in the psyche of North America and, to my knowledge, they have never been seriously challenged in the media or in public discourse.

\section{Rethinking ALE in Postsecondary Education}

While more research and discussion are needed on literacy classism in society, we need to understand how literacy classism impacts our own practice. In the absence of postsecondary research, we can turn to recent research in higher education. Rosinger et al. (2016) reported on what they called a "prestige economy" in North American universities. They found higher education resources "are not distributed randomly" in universities (p. 33). Instead, the "driver for resource segmentation" (p. 34) is the simultaneous pursuit of "money and prestige" ( $\mathrm{p}$. 48). Greater resources and more prestige were allocated to those faculties able to raise significant external research funding. Departments such as engineering, law and medicine were "high resource" faculty (p.48). They received more internal resources, more autonomy, and more prestige than "low resource" faculties such as humanities, education and human services. Low resource faculty typically could not secure significant external funding and, therefore, had to rely on "the favour of administrators" (p. 45) for their resources and they also had to carry larger teaching loads. 
I am not aware of similar research regarding our postsecondary systems but I can draw on my own experience whereby more resources and prestige are typically awarded to "high resource" programs such as nursing, business and instructional technology since they can enter major training and research contracts with corporations or the health sector. Low resource programs such as social work, education and our ALE programs, by contrast, rely on "the favours of administrators" for resources. These "favours" typically extend through our institutions to sponsors' board tables, not unlike the one I sat at in that earlier life that I mentioned earlier. For all these reasons, our vulnerable ALE programs are typically placed on the bottom rung of our institutions' ladder of resources and prestige.

\section{Towards a New Discussion}

If we are to see any real change for our learners and our practice into the $21^{\text {st }}$ century, I hope the following topics might be explored:

- Learners need a far more significant voice in what is, after all, their own future. If even a third of our learners and graduates were to write to political decision-makers lobbying for adequate, stable funding, the thousands of letters could not be ignored.

- Raising learner awareness of social structures, inequalities, human rights and the potentialities of democratic change should be a major curriculum objective.
- International Literacy Day was established by UNESCO in 1965 to "actively mobilize the international community and promote literacy as an instrument to empower individuals, communities and societies." Every September $8^{\text {th }}$ should be a day of media exposure with "marches for literacy" involving large numbers of learners. Delegations from across the volunteer and postsecondary systems should lobby decision-makers for change on September $8^{\text {th }}$. We need to be visible.

- If practitioners were to unionize across states and/or provinces, it would build a major voice for change. Imagine if states and/or provinces went on strike. If they did, the USA and Canada would definitely hear our issues.

- Finally, we need greater professional credibility. While few fields can rival ours for unselfish dedication, today's professional norms demand demonstrable skills and a verifiable knowledge base. Unfortunately, gaining professional development at the university level includes lobbying universities and state/provincial governments to make more ALE programs available, along with subsequent incentives for participating.

In closing, while I realize not all will agree with these suggestions, few of us entered the field to become "political," I nevertheless ask one last question: "Can we agree it is time for a new conversation?" If we don't name the elephant in the room-give it a push-who will? 


\section{References}

Beder, H. (1991). Adult literacy: Issues for policy and practice. Krieger.

Encyclopedia Britannica (1953). Adult education. University of Chicago.

Fischer, R. (2003). A history of reading. Reaktion Books Ltd.

Harr, J.E. (1988, December). The crusade against illiteracy. Saturday Evening Post, pp. 42-48.

Hechinger, F. (1987, June 2). What illiteracy isn't. New York Times, pp. III-7.

Quigley, A. (1997). Rethinking literacy education. Jossey-Bass.

Quigley, A. (2005). Literacy. In L.M. English (Ed.). International encyclopedia of adult education, (pp. 381387). Palgrave Macmillan.

Quigley, A. (2017). Will anything be different in the $21^{\text {st }}$ Century? PAACE Journal of Lifelong Learning, 26, 39-54.
Rosinger, K. O., Taylor, B. J., Coco, L., \& Slaughter, S. (2016). Organizational segmentation and the prestige economy: Deprofessionalization in high-and low-resource departments. The Journal of Higher Education, 87(1), 27-54.

Stevens, S. (1987). The anatomy of mass literacy in nineteenth century United states. In R. Arnove \& H. Graff (Eds.). National literacy campaigns (pp. 99-122). Plenum Press.

Verner, C. (1967). Pole's history of adult schools. Adult Education Associates of the U.S.A. (Original work published, 1816).

Zacharakis, J., Becker Patterson, M., \& Quigley, A (2021). Working class, social class, and literacy classism. In T.S. Rocco, M.C. Smith, R.C. Mizzi, L.R. Merriweather, \& J.D. Hawley (Eds.), The handbook of adult and continuing education (2020 ed., pp. 420-427). Stylus. 